\title{
Thematic Teaching Materials Based on Interactive Multimedia in Elementary School
}

\author{
Muhammad Nuraripin, Suherli Kusmana Jaja \\ Sekolah Pascasarjana Universitas Swadaya Gunung Jati, Cirebon, Jawa Barat, Indonesia
}

Email address:

aripinraden@gmail.com (M. Nuraripin)

\section{To cite this article:}

Muhammad Nuraripin, Suherli Kusmana Jaja. Thematic Teaching Materials Based on Interactive Multimedia in Elementary School. International Journal of Secondary Education. Vol. 9, No. 2, 2021, pp. 62-73. doi: 10.11648/j.ijsedu.20210902.15

Received: May 20, 2021; Accepted: June 1, 2021; Published: June 23, 2021

\begin{abstract}
This study aims to obtain thematic teaching materials based on interactive multimedia in elementary schools. This research uses Research and Development (R\&D) method with research procedure using ADDIE model. The teaching materials Interactive multimedia-based are developed by fulfilling five stages, namely: needs analysis, learning design, development design, trial and product revision. For the determination of the feasibility level of interactive multimedia-based teaching materials, a validation test carried out by material experts by obtaining an average score of $91.25 \%$ which means is very good. In addition, it is validated by media experts by obtaining an average score of $93.06 \%$. Furthermore, the feasibility test was conducted to $4^{\text {th }}$ class of elementary school teachers based on criterias 1) content eligibility, 2) presentation, 3) language use, and 4) graphics by obtaining a score of $95.83 \%$ which means is very good. Based on this, it can be stated that thematic teaching materials of interactive multimedia-based for elementary school students are eligible for use in elementary schools.
\end{abstract}

Keywords: Interactive Multimedia, Thematic Teaching Materials, and Elementary School

\section{Introduction}

The development of thematic learning models is as part of the humanization process in students in elementary schools / madrasah ibtidaiyah which has implications on various other components in the educational interaction system, one of which is teaching materials of supporting. The implications of the thematic learning model in the development of teaching materials lies in two aspects, namely on the material (content) of the teaching materials and the teaching materials themselves. Prastowo states that learning materials (teaching materials) are one component of the learning system that plays an important role in helping students to achieve basic competency and competency standards [1]. In the perspective of curriculum 2013 this competency is called core competency and basic competency. Broadly speaking, the teaching materials contain knowledge, skills, and attitudes or values that students must learn.

Based on the study of needs analysis conducted by researchers to the respondents of teachers of $4^{\text {th }}$ class SDN 3 Ambulu on the type of thematic teaching materials in the form of books specifically indonesian language subjects, do not exist yet. In this case because they still use the theme book. Teaching materials in the form of interactive multimedia in schools have not been maximally used by teachers to support learning by using media. So the learning process is only one-way which is centered on the teacher. Therefore, based on this ran teaching materials in the form of interactive multimedia needed by teachers to support creative learning.

So far, the book that has been the handbook of students is only a package book from the government and there is no teaching materials available to support students' learning activities. lack of teaching materials can also affect students' spirit in acquiring knowledge. In addition, the characteristics of the implementation of the curriculum 2013 should be able to stimulate students' skills in critical thinking and creativity until they can create or produce works. Researcher hope that learning is at a higher level in both cognitive, affective, and psychomotor indicators. This can be strengthened by the results of the respondents of $4^{\text {th }}$ class elementary school teachers who state from the use of element of the material aspects type obtained 3.76, elements of media aspects type obtained 3.83. So the average score obtained is as much as 3.8 (very need). In this case, it means that the multimedia teaching materials in the form of textbooks and video media 
for $4^{\text {th }}$ class elementary students as teaching materials to help educators or teachers through the appropriate learning process in the classroom.

The core of education is actually in the educational process or the learning process. A good learning process must be planned carefully and thoroughly. The planning can be seen from the aspects of strategy, methods, teaching materials, learning media, or other aspects that support the learning process.

The use of the appropriate learning strategies, methods and media can create a fun learning process for students. The implementation of learning itself can not be separated from the learning guidelines, namely the curriculum. According to the regulation of the Minister of Education and Culture No. 67 tahun 2013 concerning the Basic Framework and Curriculum Structure of Elementary Schools / Madrasah Ibtidaiyah, it was decided that the Curriculum 2013 was implemented in the 2013/2014 school year. The implementation of curriculum 2013 is still in the process of development, has been implemented simultaneously in all schools in Indonesia. However, the implementation of curriculum 2013 is still not maximized yet, so it takes various efforts from all parties concerned to achieve the goals what expected by curriculum 2013 [3].

Thematic learning can be defined as a learning activity by integrating the material of several subjects in one theme/topic of discussion.[6] stated that thematic learning is an effort to integrate knowledge, skills, values, or attitudes of learning, as well as creative thinking using themes. From the statement, it can be asserted that thematic learning is done with the intention of improving and improving the quality of education, especially to compensate for the dense curriculum material. In addition, thematic learning will provide integrated learning opportunities that emphasize more on the participation / involvement of students in learning. The integration in this learning can be seen from the process or time aspect, the curriculum aspect, and the teaching and learning aspect.

Advances in computer technology, information technology and communication technology are developing very rapidly. Such advances have had a tremendous influence on various areas of human life. Unwittingly, computers have played a role in society in helping the smooth human activities in various fields, one of which is education.

Basically, in general the learning media in education is called media. As described previously, there are various components in the student's environment that can stimulate them to think [5]. In general, the benefits that can be obtained from the use of multimedia learning is that the learning process is more interesting, more interactive, the quality of student learning can be improved and the teaching and learning process can be done anywhere and anytime, and the student's learning attitude can be improved.

Education experts often recommend that in carrying out the learning process teachers should use a complete media, according to the needs and touch various senses. To meet that need, the use of multimedia is one of the good alternative choice for memorable teaching and learning.

Based on these problems, the author intends to develop thematic teaching materials based on multimedia learning in elementary school. So far, thematic learning using multimedia learning in the classroom is still lacking so it needs better development. Thus the author is interested in developing multimedia learning so that the learning process is interesting, effective and easy in learning and understanding thematic learning given by teachers. In addition, multimedia-based thematic learning can also inspire teachers to be more creative in the use of media. Therefore, the author chose the title "Development of Interactive Multimedia-Based Thematic Teaching Materials and Their Implementation in Learning in $4^{\text {th }}$ class elementary school".

\section{Theoretical Foundation}

Teaching materials are an important component used in learning activities. Teaching materials have the main function as the delivery of material from or the content of the subject.

Teaching materials have a major role in learning including in thematic learning. Because thematic learning is basically a combination of various disciplines that are quite deep.

The concept of teaching materials in scientific studies has many understandings, according to Prastowo teaching material is a set of materials that are arranged in a system, whether written or not, so as to create an environment or atmosphere that allows student to learn [1]. There are also those who argue that teaching materials are information, tools, and texts that needed by teachers or instructors for the planning and reviewing of learning implementation. This view is complemented by Pannen that the teaching material is a systematically arranged material or subject material, which teachers and students use in the learning process. Sajdati [1].

Teaching materials are whole in a single learning unit and are designed to certain limitations. Teaching materials are a set of learning tools or tools that contain learning materials, methods, limitations, and ways of evaluating that are designed systematically and interestingly in order to achieve the expected goals, namely achieving competence or subcompetence with all its complexity. Widodo \&Jasmadi (Lestari 2013:1)

Actually the teaching materials are to help teachers in implementing learning. According to the National Center for Vocational Education Research Ltd [4] teaching materials are all materials used to assist teachers or instructors in carrying out the learning process in the classroom. The material in question can be either written material or unwritten material.

The teaching material of a device is intact in its structure. Based on the website dikmenjur (2010) "teaching materials are a set of materials / substances of learning (teaching material) that is arranged systematically, displaying a full figure of competence that will be mastered by students in learning activities".

There are a number of principles that need to be considered in the preparation of teaching materials or 
learning materials. Principles in the selection of learning materials include the principles of relevance, consistency, and adequacy [4].

The principle of relevance means interconnectedness. Learning materials should be relevant or have something to do with achieving basic competency and competency standards. For example, if the competency that students are expected to be mastered is in the form of memorizing facts, then the learning materials taught must be in the form of facts or memorization materials.

Teaching materials must be consistent with the implementation of basic competencies. These basic competencies must be mastered by students.

The principle of consistency means there are consistency between teaching materials and basic competencies that must be mastered by students. For example, the basic competencies that must be mastered by students of four kinds, then the teaching materials that must be taught must also include four kinds.

The principle of sufficiency means that the materials taught should be adequate in helping students master the basic competencies taught. The material should not be too little, and should not be too much. If too little will be less helpful to achieve basic competency and competency standards.

Teaching materials consist of a series of parts that are then integrated, so that it becomes a whole building that deserves to be called teaching materials.

Printed teaching materials consist of a composition of parts that are then integrated so that it becomes a whole building that deserves to be called teaching materials [8].

The composition or building of teaching materials is what is meant by the structure of teaching materials. As mentioned earlier that each form of teaching materials has a different structure. Therefore, we need to understand each form of teaching material in order to make various teaching materials well [1].

Integrated thematic learning is one of the approaches in integrated instruction which is a learning system that allows students, both individually and in groups, to actively explore and discover scientific concepts and principles holistically, meaningfully and authentically [9].

The classification of thematic teaching materials mainly refers to Triyanto's explanation which reveals that based on the form of learning activities, the teaching materials can be classified into three types [2], namely:

1) Teaching materials to teach as facilitators and students to learn on their own.

2) Teaching materials for teachers as a single source and students self-learning Teaching materials for teachers as presenters of teaching materials that was choosed or developed.

We need to compile a map of teaching materials because the map of teaching materials has many uses. According to [1] the usefulness of teaching materials includes, namely: first, to know the amount of teaching materials that must be written; second, to know the sequence of teaching materials like what (the sequence of teaching materials is needed in determining the priority of writing); and third, to determine the nature of the teaching materials, whether dependent or independent.

According to [1] about thematic terms according to the Great Dictionary of the Indonesian Language "thematic" are defined as "with regard to themes"; and "theme" itself means "point of mind; the basis of the story (entrusted, used as the basis for composing, composing poetry, etc.).

There are three integrated learning models used and developed in the Primary School Teacher Education program, namely the conneted model, the cobweb model (webbed) and the integrated model [7].

There are several plots or steps in developing plan of the thematic learning implementation according to [7] covering six stages, namely:

1. Implementing the subjects that will be integrated

2. Learn basic competencies and indicators of the content or lessons to will be integrated.

3. Select and assign unifying themes/topics

4. Create a matrix or chart of basic competency relationships and unifying themes

5. Develop a syllabus of integrated thematic learning

6. Develop a plan of integrated thematic learning implementation.

The advancement of computer media provides some advantages for activities of audio visual production. This advantage will make learning easier in schools. In recent years computers have gained great attention for their ability to be used in the field of learning activities. The use of computers is now a major need in learning.

Interactive multimedia is a medium that combines text, graphics, video, animation and sound to greet a message and information through electronic media such as computers and other electronic devices. According to Robin and Linda (samiyantosolo.wordpress.com) Interactive multimedia is a tool that can create dynamic and interactive presentations, which combine text, graphics, audio animations and video images.

The multimedia-based learning process depends on the learning model used. Heinich et al (1986), said the learning model using multimedia can be in the form of drill and practice models, tutorials, games, simulations, discovery, and problem solving [10].

Multimedia learning provides benefits in some teaching and learning situations. [9] states that "Instructional Multi Media (IMM) has the potential to accommodate people with diferent learning style". What this means is that interactive multimedia can accommodate different ways of learning. [9] states that interactive multimedia has the potential to create a multisensory environment that supports a particular way of learning.

One of the areas (domains) that get a lot of attention in the study of educational technology is the field of development. The root of this domain is directed at the production of media ranging from print media, audivisual, to computer technology and integration of computer-controlled technology. According to Gustafson and Branch [4] when people mention 
development, there are three things; first, the product development even though it is produced is an improvement of the existing product or new products produced through development. Secondly, the term development refers to procedures, stages, systemic and systematic hierarchies that are done to produce something. Third, development is always related to the model, both classroom-oriented models such as the development of teaching materials, strategies, media, methods, and evaluation of learning, product-oriented models such as media and technology. It's all a development to produce something meaningful new in the process of creating, leveraging, and managing the media and technologies used in learning.

After design of multimedia learning used is clear, next we think about how to develop multimedia learning. To be able to develop multimedia learning according to Sudhata and Tegeh (Sadiman, 2006:100) divides into six steps, namely:

a. Analyzing students' needs and characteristics.

b. Formulation of instructional goals.

c. Formulation of material items

d. Developing measuring tools for success

e. Media scriptwriting.

f. Conduct tests and revisions.

The purpose of the evaluation of multimedia learning programs is to find out of:

1) Whether or not multimedia learning is needed to repaired, in partialy or in completely.

2) Whether or not the resulting program can be applied in other place with the same targets or a different target or in the same place with a different target.

3 ) In terms of language, sudents understand or not from the simplicity of the language used in multimedia learning.

4) The clarity of the delivery of learning message from music and sound effect used.

5) Whethet or not sequence of multimedia learning is appropriate

6) Whether or not learning goals are achieved with multimedia learning.

7) Whether or not knowledge/skills improvement occurs after utilizing multimedia learning.

8) Location of multimedia learning appeal (on title, material/message, color, layout and so on) (Sudhata \& Tegeh, 2015:48).

According to Sadiman (Sudhata \& Tegeh: 2015) there are two kinds of media evaluation, namely formative evaluation and sumative evaluation. Formative evaluation is the process of collecting about the effectiveness and efficiency of learning materials (including media) and sumative evaluation is to determine whether the media created can be used in certain situations and to determine whether the media is truly effective.

\section{Methodology}

This research is conducted on experts, namely material experts and media experts as well as teacher of $4^{\text {th }}$ class at
SDN AMBULU, Losari Subdistrict, Cirebon. Product trials through assessment questionnaire of experts and teacher of $4^{\text {th }}$ class. Product that have been produced and validated by experts as well as elementary school teacher but can not be tested on students because of the covid-19 pandemic. The next, researcher will attempt to trial the product on the students.

The method used in this research is the research and development method of ADDIE model. The development procedure carried out in this study was to produce the thematic teaching material interactive base on multimedia in elementary school. The explanation of the development of thematic teaching materials based on interactive multimedia ADDIE model as follows.

\section{A. Analysis Stage}

This analysis is conducted to find out what the goal of the development of this teaching material and for whom this teaching material is intended. Several stages of analysis are: media and material analysis, needs analysis, student characteristics analysis, and educational technology analysis, which will be described as follows:

1) 1) Curriculum and Material Analysis

The selection of Indonesian subject matter taught in thematic teaching materials is the first step in curriculum analysis. Material analysis is done with the aim to determine the needs in the development of learning tools. Analysis of this material can be done by looking at the curriculum used in the school which is used as a research site so that the material contained in thematic teaching materials that will be developed in accordance with the competencies that must be mastered by the students and conducted by the dissemination of questionnaire given to teachers of $4^{\text {th }}$ class at SDN 3 Ambulu, Cirebon Regency.

The standard of competence used in this research is understanding knowledge (factual, conceptual, and procedural) based on its curiosity about science, technology, art, culture related to eye-catching phenomena and events as well as try, process, and study in the concrete realm (using, parsing, stringing, modifying, and creating) and abstract realms (writing, reading, calculating, drawing, and composing) according to those studied in schools and other sources that are similar in point of view/theory.

Based on curriculum analysis, can be identified the formulation of basic competencies that are further developed indicators of the Indonesian language material presented. $\mathrm{Sk} / \mathrm{KD}$ formulation and indicators that become a reference for making of teaching materials.

The analysis carried out in this research is an analysis based on the subjects of thematic books is specialized in Indonesian subjects. Examples of text material used as data in this study are Indonesian subjects in the form of text or manuscript (written) and also in the form of video (oral). Material data in the form of text before being analyzed, firsly, the researcher change it into the form of text by selecting the existing materials in the thematic book.

The result of the text transcript that has become the form of writing (text) is then carried out the editing process. This 
is because it is still mixed with other subject matter that allows for errors in the transcriptor process so that the text that emerges from the thematic book has not been or is not appropriate. The example of material that undergoes the transcriptor process is Indonesian material. From the results of this analysis is hoped to provide benefits among others is to be a knowledge for researcher about mapping Indonesian language materials with other subjects in thematic books, additional reference materials to be used as examples of Indonesian language materials that will be conveyed to students, knowledge and insights for learners, and as materials to develop interactive multimedia teaching materials that are appropriate, needed, and can increase the motivation of students in following the learning process.

Based on the results of the analysis of thematic books on their respective sub themes, in general, researcher can explain again that each theme has a sub theme and each sub theme has learning namely learning of one to six. Each learning has a specific subject, namely, PKn, Bahasa Indonesia, IPS, SBDP, and for the subjects of Mathematics and PJOK itself. Meanwhile from each learning is analyzed in accordance with KD Bahasa Indonesia. Each KD has knowledge and skills.

Materials developed by researcher taken from the thematic book Bahasa Indonesia in $4^{\text {th }}$ class namely 1) Theme 1: The Beauty of Togetherness, 2) Theme 2: Always Saving Energy, 3) Theme 3: Caring for Living Things, 4) Theme 4: Various Jobs, 5) Theme 5: Pahlawanku 6) Theme 6: My Ideals, 7) Theme 7: The Beauty of Diversity in My Country, 8) Theme 8: My Residential Area, 9) Theme 9: Rich in My Country.

Then researcher analyze from each material, each theme there is an material of Indonesian language in accordance with basic competencies (KD) namely in theme 1: The beauty of Togetherness has KD (3.1 and 4.1), Theme 2: Always Save Energy has $\mathrm{KD}(3.1,4.1,3.2$, and 4.2), Theme 3: Caring for Living Beings has KD (3.3, and 4.3), Theme 4: Various Works have $\mathrm{KD}$ (3.5, and 4.5), Theme 5: My hero has KD (3.7 and 4.7), Theme 6: My Ideals have KD (3.6 and 4.6), Theme 7: The Beauty of Diversity in My Country has KD (3.7 and 4.7), Theme 8: My Residential Area has KD (3.8 and 3.8) and Theme 9: Kaya Negeriku has KD (3.9 and 4.9).

In the Section Theme 1 The beauty of togetherness above contains: (1) mapping basic competencies, (2) learning objectives, (3) learning materials and student exercises that contain sections let's read with material discussing basic ideas and supporting ideas, reading reading with the theme of cultural parades, let's practice this to the extent that students' ability to explore the material that has been taught. Then the section let's listen to the theme of helping each other and closed with let's practice hopefully students are able to work as learning feedback.

Theme Part 2: Always Save Energy which contains (1) mapping KD (2) Learning objectives (3) learning materials that contain let's read with Sun and Rain materials and let's practice looking for images of the benefits of solar energy and practice about reading fan making instructions. Another part let's discuss with the group about posters.
In the Section Theme 3 Caring for Living Things that contains about (1) mapping KD (2) learning objectives (3) material let's read with the materials to fill the list of questions in preparation for interviews and exercises. Let's have a discussion about putting together a list of questions. Then another part let's observe with the material make a question using the standard sentence.

Section 4 Theme Various Works that contains (1) mapping KD (2) learning objectives (3) contains material let's read material about the understanding of literary works and literary elements, other sections let's write about figures and affirmations, and let's read about ants and grasshoppers and closed by let's practice answering questions that have been provided in the book.

This 5 Hero Theme section contains (1) KD mapping (2) learning objectives there are two parts (3) containing material with sections let's read, and let's practice. Section let's read about the text reading. Let's practice assessing students so that students can retell the content of the story using their own language.

Theme $6 \mathrm{My}$ goal is to contain (1) KD 3.6 mapping. and 4.6 (2) learning objectives there are two parts (3) about the material let's read discuss about the research of poetry. Another part let's practice arranging poetry lines into poetry verses.

The Theme 7 Beautiful Diversity section in My Country contains (1) mapping KD 3.7 and 4.7 (2) learning objectives (3) material let's read a look at the reading text about Ethnic Groups in Indonesia, and let's discuss creating a group together so that students are able to mention new information about the bagsa tribe in Indonesia.

Section 8 Theme Area Where I Live yautu contains about (1) mapping KD with code 3.8 and 4.8 (2) learning objectives (3) material let's read the fictional story Origin of Telaga Warna and let's discuss with this activity students can tell about fiction stories.

The Theme Section 9 Kaya Negeriku contains (1) mapping KD (2) learning objectives (3) material let's read with the contents of the material Energy Sources that can not be updated so that students understand the relationship of humans with the environment with care.

Researchers see from the aspect of the form that is between Theme 1 to Theme 9 above that the researchers argue that there are differences in terms of Basic Competencies (KD) on the theme there are some KD that are not in accordance with its application for example in Theme 2 there are two KD because researchers look at KD others have one KD. Then for $\mathrm{KD} 10$ in the book there is no disilabus curriculum there. The results of the analysis of the material obtained showed that in terms of its form was found almost the same that includes mapping $\mathrm{KD}$, learning objectives applied at the beginning before the material and material.

In this chapter, researchers can also tell that there are differences in the material presented. The difference in this material is due to the difference of each theme in each thematic book for example the theme 1 Beautiful Togetherness with Theme 2 Always Save Energy it is a 
description with a certain theme in the thematic book.

Based on the results of the analysis of the thematic book above, researchers think it is necessary to be developed into a teaching material that is easy, practical, and efficient so that it is expected to be able to motivate teachers and students in the teaching and learning process so that researchers need the development of teaching materials in the form of multimedia.

2) Needs Analysis

The purpose of this analysis is to know the picture of the real conditions in the field. The author conducts an analysis of the needs of the potential and problems of Thematic learning in basic competencies Indonesian language that have occurred during this time in elementary school. The analysis was conducted by giving a questionnaire of needs to the teacher and an interview to one of $4^{\text {th }}$ class teacher at the school.

3) Teacher Characteristics Analysis

Characteristic analysis needs to be done because teacher characteristics are a target in the development of teaching materials. The characteristic analysis was conducted on teachers at SDN 3 Ambulu In Losari Subdistrict, Cirebon. At this stage the analyzed characteristics or background of the teacher are related to the use or operation of the media or smartphone used by the teacher. In addition, researchers also analyzed teachers' interest in teaching materials using android or smartphone. This analysis is done by conducting interviews with $4^{\text {th }}$ class teachers as well as giving questionnaires of the needs analysis that was filled in by teachers so that in the development of teaching materials can be adjusted to the characteristics of teachers.

4) Education Technology Analysis

This analysis of educational technology is done to know whether the place that will be used as a research object can support the implementation of research. In addition, to know various facilities and infrastructures in schools that can support the learning process such as providing an infocus, speakers, proyectors, and others. The way to know this is by using questionnaire to $4^{\text {th }}$ class teachers at SDN 3 Ambulu Losari Subdistrict, Cirebon Regency. Teaching materials made in the form of digital teaching materials using Smartphones and utilizing multimedia internet networks.

Technology analysis is done by discussing with lecturer supervisor, class teachers, and experts of digital teaching materials to adjust the application will be used with specified material.

5) Teaching Materials Analysis

The analysis of teaching materials is done to know the utilization of teaching materials in thematic learning in elementary schools. The first thing is done after the researcher compile and make the concept of teaching materials based on the direction and approval of the lecturer supervisor, then the concept of teaching materials in the form of video teaching materials is validated to experts and practitioners. Experts who will validate the teaching materials of this video are people who have competence in the field of teaching materials to assess the feasibility of teaching materials that have been made, in this case lecturer who have been recommended by the lecturer supervisor.

In this study, the experts recommended to validate multimedia-based video teaching materials were Dr. Surya Amami Pramuditya, M. Si from UGJ Cirebon and Dr. Indrya Mulyaningsih, M. Pd. as a material expert validator from IAIN Syeh Nurjati Cirebon. Meanwhile, Ahmadin is a teacher in elementary school in the same subjects as the teaching materials made, namely teachers of $4^{\text {th }}$ class. This senior teacher comes from the school chosen to be the object of research in this case the teacher of $4^{\text {th }}$ class at SDN 3 Ambulu Losari Subdistrict, Cirebon Regency. In performing validation, both validators are given an assessment sheet in the form of a validation instrument containing statement items related with the assessed aspects of the video teaching materials made. The results of further validation of teaching materials will be processed by researchers so that in the end it can be concluded that the video teaching materials that have been made worthy or not yet eligible to be used as teaching materials in the learning process in the classroom.

\section{B. Design Stage}

1) Learning/Instructional aim setting

In this draft of Indonesian book, students are expected to be able to easily use Indonesian language books on thematic books in learning. The teaching materials selected from thematic books are materials related to Indonesia language Elementary School in $4^{\text {th }}$ class.

2) Presentation of materials

Materials that can be collected based on the analysis of needs that have been done, among others:

a) Researcher refer to school books and LKS of $4^{\text {th }}$ class Elementary School from various theme books ranging from theme 1 to theme IX.

b) To create multimedia-based digital teaching materials, researcher chose to use video because it supports to load animations, images, and others. The most interesting thing about this video is that it allows the learning process to run both in school and outside the school. In addition, videos can be used through youtube so that the learning process can be done anytime and anywhere on condition that there is a connection or connection with the internet network. In this video, teachers can include the content they need in the learning process and open active interactions in an online discussion.

The content of the material is provided according to the needs of the students. The content of the material contains the introduction of the material; basic competencies; content with text, images, narration, charts, animations, and videos; examples of questions and discussions; knowledge column; discussions; puzzles remember, test videos; about info; test videos; and a behavioral checklist that serves to know if the student has mastered or understood the sub-material that has been studied. If the student has not mastered the sub material, then the student cannot proceed to the next sub-material.

3) Writing Manuscripts of Multimedia Teaching Material and Material

The scrift of multimedia teaching material and material is the material planning presented in the learning teaching materials by 
referring to the analysis results that has been done at the previous stage. The following can be seen the composition of the material presented in the media on Table.

Researchers divide media script writing into two, namely concept design and design of digital teaching materials software.

4) Design of digital teaching material concept

The design or design of the concept and software of multimedia-based digital teaching materials refers to three components, namely: the appearance, materials, and instructions for accessing the website address and. The first component is the display. The designed display consists of: the main page in the form of title recognition and the author of digital teaching materials accompanied by images and narration and there is text, video, images, and animation.

The second component is material. The content of the material is tailored to the characteristics of the learner. The content of the material on multimedia is delivered using images, animations, videos, charts, narration or text. Narration and text serve to assist learners in clarifying the material. At the beginning of the digital teaching materials created, researchers begin by creating a concept map to help students in building the context of the material to be delivered. In addition to the material, there are also examples of questions and discussions. Before students do the learning activities, students are given examples and discussions of the materials that have been delivered so that it is expected that students can do the task correctly.

In this multimedia-based digital teaching material, learning activities consist of 9 theme activities from 10 basic competencies. Each basic competency contains 2 learning activities. The learning activities that will be conducted by students contain instructions, learning objectives, and video views related to the learning materials so that students are expected to know what to achieve or obtain from the learning process. In addition to materials, this digital teaching material also contains evaluas. Evaluation is loaded with the aim of knowing or measuring the extent to which students understand the materials conducted through this interactive multimedia-based digital teaching material.

5) Formulation of Evaluation Tools

In addition to the preparation of learning scripts and scenarios, the preparation of instruments was carried out. The preparation of assessment instruments aims to evaluate the products that have been made. Instruments used include digital teaching materials and materials by experts and practitioners (validation instruments) and questionnaires of students' responses to digital teaching materials tested in small groups.

\section{Development}

1) Manufacture of Multimedia Teaching Materials

The creation of multimedia teaching materials that starts from typing materials, training questions, evaluations and continued by including images, animation and navigation making, as well as video recordings. The creation of digital teaching materials based on interactive multimedia is in accordance with the outline of the contents of the teaching materials and the design of the development of digital teaching materials. Multiple displays of digital teaching materials.

2) Revision of Interactive Multimedia Teaching Material

Once the interactive multimedia teaching materials are completed, the next step is the assessment or validation of digital teaching materials by experts and practitioners. Experts and practitioners are given an assessment instrument in the form of validation instruments to provide value, criticism, and advice on digital teaching materials. After both validations are done, if there are still suggestions or criticisms that must be corrected on the digital teaching materials, then the researcher will make revisions. The revised interactive multimedia teaching materials are then reassessed by experts and practitioners so that they are eligible to be brought to the next stage.

\section{Implementation Stage}

Interactive multimedia teaching materials that have been validated by experts are then tested in the field. Implementation of Interactive Multimedia teaching materials that have been validated by experts and teachers of 4th class Elementary School then want to be tested to 4th class elementary school students. This is an obstacle due to the covid-19 pandemic so that the researcher can not be directly tested to students.

Thus, the trials to 4th class students could not be carried out to amplify interactive multimedia teaching materials, indeed to be tested online can be carried out but the research is not maximal to be tested, therefore to replace in the study and implenetasi interactive multimedia teaching materials in place of 4th class teachers in elementary school, by assessing interactive multimedia teaching materials with research instruments that have been provided by the researcher.

Assessments were made by grade IV teachers in elementary school on Tuesday, February 9, 2021. Researchers provide teaching material assessment instruments both with textbooks that have been made and multimedia video. Interactive multimedia teaching materials were then graded by grade IV teachers at SDN 3 Ambulu Losari Subdistrict, Cirebon Regency.

The assessment conducted by the grade IV teacher in private means that the assessment in accordance with his own conscience is no pressure on anyone. Upon completion of the assessment, the instrument is returned to the researcher. The instruments that have been filled will then be processed and analyzed by the researcher.

With the results of this processing will be known whether interactive multimedia teaching materials can include criteria feasible or effective to be implemented in learning.

\section{Evaluation Stage}

At this stage, researcher analyzed data from the filling of evaluation sheets obtained from experts, and teachers of teaching material or material. This analysis is based on the results of validation instruments expert and practitioner as well as student response questionnaires. If there is any discrepancies with the experts in the assessment of interactive teaching materials the researcher will reanalyze and reevaluate. 


\section{Results and Discussion}

Result

Material Expert Assessment

The expert assessment of teaching materials consists of

a. Content Feasibility Aspects four aspects, namely the feasibility of content, the feasibility of language, the feasibility of presentation, and the feasibility of graphics. The general description of the results of the assessment of the four aspects can be seen in the following Tables:

Table 1. Validation Results of Teaching Materials Expert on Aspects of Content Feasibility.

\begin{tabular}{llll}
\hline No & Assessment Indicator & Presentage of score Acquired (\%) & Category \\
\hline 1 & Suitability to student needs & $100 \%$ & Very good \\
2 & The truth of the material substance & $100 \%$ & Very good \\
3 & Suitability to theory & $100 \%$ & Very good \\
4 & Problem according to indicators & $100 \%$ & Very good \\
5 & About using contextual stimulus & $75 \%$ & Good \\
& Score & $95 \%$ & Very good \\
\hline
\end{tabular}

b. Aspects of Language Feasibility

Table 2. Validation Results of Teaching Materials Experts on Aspects of Language Feasibility.

\begin{tabular}{llll}
\hline No & Assessment Indicator & Presentage of score Acquired (\%) & Category \\
\hline 1 & Readability & $100 \%$ & Very good \\
2 & Clarity of information & $100 \%$ & Veru good \\
3 & Conformity with Indonesian rules & $75 \%$ & Good \\
4 & use of language Effectively and efficiently & $100 \%$ & Very good \\
5 & The suitability of the image or illustration with the language in the book & $75 \%$ & $90 \%$ \\
& Average Score & Good & Very good \\
\hline
\end{tabular}

c. Aspects of Presentation Feasibility

Table 3. Validation Results of Teaching Materials Experts on Aspects of Presentation Feasibility.

\begin{tabular}{llll}
\hline No & Assessment Indicator & Presentage of score Acquired (\%) & Category \\
\hline 1 & Clarity of goal & $100 \%$ & Very good \\
2 & Order of presentation & $100 \%$ & Very good \\
3 & Presentation encourages students to think critically and creatively & $100 \%$ & Very good \\
4 & Student-centered & $100 \%$ & Very good \\
5 & Interactivity (stimulus and response) & $100 \%$ & Very good \\
6 & Completeness of information & $100 \%$ & Very good \\
& Average Score & $100 \%$ & Very good \\
\hline
\end{tabular}

\section{d. Aspects of Graphic Feasibility}

Table 4. Validation Results of Teaching Materials Experts on Aspects of Graphic Feasibility.

\begin{tabular}{|c|c|c|c|}
\hline No & Assessment Indicator & Presentage of score Acquired (\%) & Category \\
\hline 1 & Font usage (type and size) & $75 \%$ & Good \\
\hline 2 & Layout & $75 \%$ & Good \\
\hline 3 & Illustration, graphics, images, photos & $75 \%$ & Good \\
\hline \multirow[t]{2}{*}{4} & Design of the display & $75 \%$ & Good \\
\hline & Average Score & $75 \%$ & Good \\
\hline
\end{tabular}

Table 5. Assessment Results of Experts teaching materials on the four aspects.

\begin{tabular}{|c|c|c|c|c|c|}
\hline \multirow{2}{*}{ No } & \multirow{2}{*}{ Assessment Indicator } & \multicolumn{2}{|l|}{ Amount } & \multirow{2}{*}{ Average Score } & \multirow{2}{*}{ Category } \\
\hline & & Indicators & Score & & \\
\hline 1 & Feasibility of Content & 5 & 19 & $95 \%$ & Very Good \\
\hline 2 & Feasibility of Language & 5 & 18 & $90 \%$ & Very Good \\
\hline 3 & Feasibility of Presentation & 6 & 24 & $100 \%$ & Very Good \\
\hline \multirow[t]{2}{*}{4} & Feasibility of Graphic & 4 & 12 & $75 \%$ & Good \\
\hline & Grand Total & 20 & 73 & $91,25 \%$ & Very Good \\
\hline
\end{tabular}

Based on the diagram above, results of the assessment of teaching materials expert on interactive multimedia teaching 
materials products show that the aspect of feasibility of presentation consisting of 6 indicators has the highest average score (4.0) compared to aspects of content feasibility, language, and graphics. While the graphic aspect consisting of 4 indicators has the lowest average score of 3.0. Another graph is the feasibility of the content has a value of 3.8 with a presentation of $95 \%$ with a very good and decent category, and the language has a value of 3.6 with a presntasi of $75 \%$ categorized very well also categorized as worthyBased on the diagram above, the results of expert assessment of teaching materials on interactive multimedia teaching materials products show that the aspect of feasibility of presentation consisting of 6 indicators has the highest average score (4.0) compared to aspects of content feasibility, language, and graphics. While the graphic aspect consisting of 4 indicators has the lowest average score of 3.0. Another graph is the feasibility of the content has a value of 3.8 with a presentation of $95 \%$ with a very good and decent category, and the language has a value of 3.6 with a presntasi of $75 \%$ categorized very well also categorized as feasible.

\section{Assessment Of Media Expert}

Assessment of media expert consists of four aspects, namely the feasibility of display aspects, content feasibility, writing feasibility, and graphic feasibility. The general description of the assessment results of the four aspects can be seen in the following tables:

e. Aspects of Display Feasibility

Table 6. Validation Results of Media Experts on Display Feasibility Aspects.

\begin{tabular}{llll}
\hline No & Assessment Indicator & Presentage of score Acquired (\%) & Category \\
\hline 1 & Suitability of background selection & $75 \%$ & Good \\
2 & Kesesuaian proporsi warna & $100 \%$ & Veru good \\
3 & Proposional layout (text layout with images) & $75 \%$ & Good \\
& Score & $83,33 \%$ & Very good \\
\hline
\end{tabular}

\section{f. Aspects of Content Feasibility}

Table 7. Validation Result of Media Experts on Aspects of Content Feasibility.

\begin{tabular}{llll}
\hline No & Assessment Indicator & Presentage of score Acquired (\%) & Category \\
\hline 1 & Suitability of the cover display & $100 \%$ & Very good \\
2 & Interesting of page tittle design & $100 \%$ & Very good \\
3 & Suitability of image interest with material & $75 \%$ & Good \\
4 & Suitability of Image & $75 \%$ & Good \\
5 & Suitability of Image quality & $100 \%$ & Very good \\
6 & Suitability of Image caption & $100 \%$ & Very good \\
& Average Score & $91,67 \%$ & Very good \\
\hline
\end{tabular}

\section{g. Aspek Kelayakan Penulisan}

Table 8. Validation Results of Teaching Materials Experts on Aspects of Presentation Feasibility.

\begin{tabular}{llll}
\hline No & Assessment Indicator & Presentage of score Acquired (\%) & Category \\
\hline 1 & Letter conformity & $100 \%$ & Very good \\
2 & Clarity of text to read & $100 \%$ & Very good \\
3 & The use of language Effectively and efficiently & $100 \%$ & Very good \\
4 & Readability of text & $100 \%$ & Very good \\
5 & Accuracy of Text spelling & $100 \%$ & Very good \\
& Average score & $100 \%$ & Very good \\
\hline
\end{tabular}

\section{h. Aspects of Graphic Feasibility}

Table 9. Validation Results of Teaching Materials Expert on Aspects of Graphic Feasibility.

\begin{tabular}{llll}
\hline No & Assessment Indicator & Presentage of score Acquired (\%) & Category \\
\hline 1 & Suitability of Font usage & $100 \%$ & Very good \\
2 & Font type size & $100 \%$ & Very good \\
3 & Suitability of writing colors & $100 \%$ & Very good \\
4 & Design of the display & $75 \%$ & Good \\
& Average score & $93,75 \%$ & Very good \\
\hline
\end{tabular}


Table 10. Hasil Penilaian Ahli Bahan ajar Multimedia Interaktif terhadap Keempat Aspek.

\begin{tabular}{llllll}
\hline \multirow{2}{*}{ No } & Assessment Indicator & Amount & \multirow{2}{*}{ Average Score } & Category \\
\cline { 3 - 5 } & Indicators & 3 & 10 & $83,33 \%$ & Very good \\
\hline 1 & Feasibility of Display & 6 & 22 & $91,67 \%$ & Very good \\
2 & Feasibility of content & 5 & 20 & $100 \%$ & Very good \\
3 & Feasibility of writing & 4 & 15 & $93,75 \%$ & Very good \\
4 & Feasibility of Graphic & 18 & 67 & $93,06 \%$ & Very good \\
\hline
\end{tabular}

Based on the diagram above, the results of expert assessment of teaching materials on interactive multimedia teaching materials products show that the aspect of writing feasibility consisting of 5 indicators has the highest average score (4.0) compared to the feasibility aspect of display, content, and graphing. While the display aspect consisting of 3 indicators has the lowest average score of 3.33. Other feasibility items such as Content and grapha each have almost the same value that the feasibility of the content has a value of $91.67 \%$ while the feasibility of the graph has a percentage of $93.75 \%$ is reported very well.

The comments and suggestions submitted by media teaching experts to provide input to researchers with the aim that media teaching materials can be applied in schools for students, so that learning can be fun. Some expert comments on media teaching materials produced include: that media experts ask about interactive words in interactive multimedia titles to researchers because media experts read and interpret media teaching materials in the form of videos made by researchers are still not appropriate in their application, so media experts give input on interactive multimedia words that are better interactive multimedia words in turn into repertive multimedia.

Practitioner Assessment (Teacher)

a. Material Feasibility Aspects

Table 11. Practitioners Validation Results of Teaching Materials on Aspects of Material Feasibility.

\begin{tabular}{|c|c|c|c|}
\hline No & Assessment Indicator & Presentage of score Acquired (\%) & Category \\
\hline \multirow[t]{6}{*}{1} & Feasibility of Content & & \\
\hline & suitability with the needs of students & $100 \%$ & Very Good \\
\hline & Truth of the material substance & $100 \%$ & Very Good \\
\hline & Suitability with the theories & $100 \%$ & Very Good \\
\hline & Soal sesuai dengan indikator & $100 \%$ & Very Good \\
\hline & About using contextual stimulus (images, graphs, visualizations, etc., according to the real world) & $75 \%$ & Very Good \\
\hline \multirow[t]{6}{*}{2} & Way of Language & & Very Good \\
\hline & Readability & $100 \%$ & Very Good \\
\hline & Clarity of information & $100 \%$ & Very Good \\
\hline & suitability with Indonesian rules & $75 \%$ & Very Good \\
\hline & The use of language Effectively and efficiently & $75 \%$ & Very Good \\
\hline & The suitability of the image or illustration with the language in the book & $100 \%$ & Good \\
\hline \multirow[t]{7}{*}{3} & Penyajian & & Very Good \\
\hline & Clarity of goal & $100 \%$ & Very Good \\
\hline & Order of presentation & $100 \%$ & Very Good \\
\hline & Presentation encourages students to think critically and creatively & $100 \%$ & Good \\
\hline & Student-centered & $100 \%$ & Good \\
\hline & Interactivity (stimulus and response) & $100 \%$ & Very Good \\
\hline & Completeness of information & $75 \%$ & Good \\
\hline \multirow[t]{6}{*}{4} & Grafika & & Very Good \\
\hline & Font usage (type and size). & $100 \%$ & Very Good \\
\hline & Lay out & $75 \%$ & Good \\
\hline & Illustration, graphics, images, photos & $75 \%$ & Good \\
\hline & Design of the display & $100 \%$ & Very Good \\
\hline & Average Overall Score & $92,50 \%$ & Very Good \\
\hline
\end{tabular}

b. Aspects of Media Feasibility 
Table 12. Validation Results of Teaching Material Practitioners on Aspects of Media Feasibility.

\begin{tabular}{llll}
\hline No & Assessment Indicator & Presentage of score Acquired (\%) & Category \\
\hline 1 & Display & $100 \%$ & Very Good \\
& Suitability of Background selection & $100 \%$ & Very Good \\
& Suitability of color proportions & $100 \%$ & Very Good \\
& Proposional Layout (text layout with images) & & Very Good \\
2 & Content & $75 \%$ & Good \\
& Suitability of cover view & $100 \%$ & Very Good \\
& Interesting tittle page design & $100 \%$ & Very Good \\
& Suitability of image interest with material & $100 \%$ & Very Good \\
& Suitability of Image & $100 \%$ & Very Good \\
& Suitability of Image quality & $100 \%$ & Very Good \\
& Suitability of image caption & & Very Good \\
& writing & $100 \%$ & Very Good \\
& Suitability of Font & $100 \%$ & Very Good \\
& Clarity of text to read & $100 \%$ & Very Good \\
& Use of language Effectively and efficiently & $75 \%$ & Good \\
& Readability of text & $100 \%$ & Very Good \\
& Accuracy of Text spelling & & Very Good \\
& Graphics & $100 \%$ & Very Good \\
& Suitability of Font usage & $100 \%$ & Very Good \\
& Font type size & $100 \%$ & Very Good \\
& Suitability of writing colors & $75 \%$ & Good \\
& Design the display & $95,83 \%$ & Very Good \\
\hline
\end{tabular}

Table 13. Results of Assessment of Digital Teaching Materials Practitioners on Both Aspects.

\begin{tabular}{llllll}
\hline \multirow{2}{*}{ No } & \multirow{2}{*}{ Assessment Indicator } & Amount & & \multirow{2}{*}{ Average Score } & Category \\
\cline { 3 - 5 } & Material Aspects & 21 & Score & $92,50 \%$ & Very Good \\
2 & Media Aspects & 18 & 69 & $95,83 \%$ & Very Good \\
& Total & 39 & 141 & $94,17 \%$ & Very Good \\
\hline
\end{tabular}

The results of the assessment of teaching materials practitioners on multimedia teaching materials products showed that the feasibility aspect of presentation consisting of 2 aspects of refining had the highest average score $(95.83 \%)$ very good compared to the material aspect. While the material aspect has the lowest score of $92.50 \%$ the result is Very Good and the category is Very Decent.

\section{Discussion}

Product development of interactive multimedia-based thematic teaching materials in elementary school is the development of learning materials by using interactive multimedia learning as a form of presentation (presentation) by paying attention to aspects of learning and media as the principle of learning message design.

Research and development is carried out with the aim to produce products in the form of interactive multimedia-based teaching materials while testing the effectiveness of products that can be utilized by grade IV students in elementary school as one of the strategies to improve the quality of the learning process and learning outcomes and competencies of students. Therefore, the process of research and development is carried out and begins with several stages, among others: (1) conduct preliminary studies, including observations, interviews and library studies. From observation obtained the picture that the learning conducted by teachers in the class tends to use traditional approaches, although there are actually adequate learning facilities such as computer and infocus. (2) design products to produce the initial product of teaching materials, this activity includes (a) Conducting preliminary research which includes: Identifying learning needs and objectives, determining the standard of competency of subjects, (b) Conducting learning analysis by determining more specific skills to be learned, (c) identifying the characteristics and initial behaviors of learners, and (d) writing down basic competencies and indicators; (e) Develop benchmark reference tests by developing assessment points to measure students' estimated abilities within learning objectives; (f) develop learning strategies; (3) Developing teaching materials, this activity includes the creation of storyboards followed by the collection of supporting materials such as photos, videos, audio, animations, and images needed to complete the multimedia form, (4) Implementation namely the programming activities of teaching material into multimedia form by using iSpring suite software. And the final stage is burning / printing media in the form of learning videos. (5) conduct formative evaluation and revision.

The nature of evaluation is a systematic and continuous process to determine the quality (value and meaning) of something, based on certain considerations and criteria in the framework of decision making. Arifin Zaenal (2016:5). So, evaluation is a process not an outcome. The result obtained from the evaluation activity is the quality of something, whether it concerns the value or meaning, while the activity to arrive at the awarding of value and meaning is the 
evaluation.

In this case, the evaluation of the program is interpreted as a process or effort to decrypt, collect and provide data (information) about a program as a consideration for policyholders to determine the continuation of the program.

The evaluation process is used to assign a value to the evaluated object so that the benefits or value of its intrigue can be conveyed to others.

The results of the manufacture of thematic teaching materials based on interactive multimedia for Students of $4^{\text {th }}$ class Elementary School. The validation results of teachers of $4^{\text {th }}$ class elementary school can be explained as follows.

Filling out the assessment questionnaire of $4^{\text {th }}$ class elementary school teachers on interactive multimedia-based thematic teaching materials books for $4^{\text {th }}$ class SD that has been validated.

The aspects that become the teacher's assessment of the textbook include: 1) The content of the material, which includes a. feasibility of content, b. language, c. presentation, and $d$. graphics, while media aspects: a. appearance, b. content, c. writing, and d. grafika, it can be obtained the overall average value with the number of 141 based on 2 subjects assessor. Sourced on the obtained value of the summation.

The results of the assessment of teaching materials practitioners on multimedia teaching materials products showed that the feasibility aspect of presentation consisting of 2 aspects of refining had the highest average score $(95.83 \%)$ very good compared to the material aspect. While the material aspect has the lowest score of $92.50 \%$ the result is Very Good and the category Is Very Decent.

Based on the results of the final study can be obtained information that the quality of interactive multimedia-based thematic teaching materials developed is worth diguakan in learning f in grade IV SD / MI. Thus, interactive multimediabased thematic teaching materials can be implemented in accordance with the objectives to be achieved, namely to improve the caring character and responsibility of $4^{\text {th }}$ class elementary school students.

\section{Conclusion}

Thematic teaching materials products base on Interactive multimedia developed for students of $4^{\text {th }}$ class elementary meet the requirement and are suitable for use as learning media, based on the results of expert validation of multimedia learning in the thematic teaching materials book developed shows the whole in the category of "Very good" so it is worth using in the learning process.

Validation results from material experts and learning media experts on interactive multimedia-based thematic teaching materials for learning in the developed teaching materials book showed $93.06 \%$ for material experts and $91.25 \%$ for media experts as a whole in the "Very good" category so that it is feasible to be used in the learning process.

The results of the product trials in the grade IV teacher trials at SDN 3 Ambulu Losari Subdistrict Cirebon showed that for the quality of learning materials are considered very good, while for technical quality or video display is rated $94.17 \%$ categorized as "Very Good" so it can be feasible.

\section{References}

[1] Prastowo. 2016. Pengembangan Bahan Ajar Tematik Tinjauan Teoritis dan Praktek, cetakan ke -2, Jakarta: Kencana.

[2] Prastowo Andi, 2017, Menyusun Rencana Pembelajaran (RPP) Tematik Terpadu Implementasi Kurikulum 2013 untuk SD/MI, Jakarta: Kencana.

[3] Awwaludin, 2017, Pengembangan Buku Teks Sintaksis Bahasa Indonesia, Yogyakarta: Budi Utama https://mgmpips.wordpress.com/2007/03/24/sumber-bahanajar/.

[4] Sudhata \& Tegeh, 2015, Desain Multimedia Pembelajaran, Yogyakarta: Media akademia.

[5] Kadaruddin, 2016, Media dan Multimedia Pembelajaran, Budi Utama: Yogyakarta Rusman, 2016, Pembelajaran Tematik Terpadu Teori, Praktek dan Penilaian, Jakarta: Rajagrafindo.

[6] Yaumi, Muhammad. 2018. Media \& Teknologi Pembelajaran. Jakarta: Prenademedia Group.

[7] Prastowo, Andi. 2017. Menyusun Rencana Pelaksanaan Pembelajaran Tematik Terpadu. Jakarta: Kencana.

[8] Sajdati, 2012. Modul 1 Hakekat Bahan Ajar. http://repository.ut.ac.id/4157/1/IDIK4009-M1.pdf.

[9] Rusman, 2016, Pembelajaran Tematik Terpadu Teori, Praktek dan Penilaian, Jakarta: Rajagrafindo.

[10] Munir. 2015. Multimedia Konsep \& Aplikasi dalam Pendidikan. Bandung: Alfabeta. 